\title{
Pemanfaatan Limbah Red Bigeye (Priacanthus macracanthus) Surimi Sebagai Alternatif Pakan Ikan
}

\section{Red Bigeye (Priacanthusmacracanthus)Surimi Solid Waste Chemical Utilization of Nutrition Content as Alternative Fish Feeding Materials}

\author{
Fifit Erliyana Safitri ${ }^{1 *}$, Muhammad Arief ${ }^{2}$, danMirni Lamid ${ }^{2}$. \\ ${ }^{1}$ Program Studi Budidaya Perairan, Fakultas Perikanan dan Kelautan, Universitas Airlangga, Surabaya \\ ${ }^{2}$ Departemen Manajemen Kesehatan Ikan dan Budidaya Perairan, Fakultas Perikanan dan Kelautan, Universitas \\ Airlangga, Surabaya \\ *fifit-e-s-fpk10.web.unair.ac.id
}

\begin{abstract}
Abstrak
Pakan satu dari beberapa komponen penting dalam kegiatan budidaya intensif. Harga pakan akan mempengaruhi biaya produksi dan keuntungan yang diperoleh dari usaha budidaya. Salah satu diantaranya yang memungkinkan untuk dimanfaatkan sebagai bahan pakan alternatif adalah limbah ikan Swangi pada produk surimi. Salah satu usaha untuk pengolahan limbah tersebut yaitu melalui proses kimiawi. Pengolahan secara kimiawi yaitu dengan cara penambahan asam organik yaitu asam formiat dan propionat. Penelitian menggunakan metode eksperimental dengan Rancangan Acak Lengkap (RAL). Perlakuan terdiri atas penambahan asam organik sebanyak $0 \%$ (P0), 1,5\% (P1), 3\% (P2), dan 4,5\% (P3) dengan masing-masing ulangan lima kali. Parameter yang diamati adalah kandungan nutrisi selama 7 hari dengan kondisi aerob.Data dianalisis dengan Analysis of Variance serta guna mengetahui perlakuan yang paling baik digunakan Uji Jarak Berganda Duncan dengan selang kepercayaan 95\%. Hasil dari penelitian menunjukkan bahwa penambahan asam dengan dosis yang berbeda pada limbah surimi menghasilkan kandungan nutrisi pakan yang berbeda sangat nyata $(\mathrm{p}<0,01)$. Kandungan nutrisi terbaik terdapat pada perlakuan P3 dengan kandungan protein kasar $(51,0048 \%)$, lemak kasar $(8,6659 \%)$, serat kasar $(3,9991)$, bahan kering $(88,6422 \%)$ dan abu sebesar $(26,011 \%)$.
\end{abstract}

Kata Kunci: asam formiat, bungkil kedelai, nutrient, asam propionate dan ikan swanggi

\begin{abstract}
Fish feed is one of the important components in an intensive aquaculture. Feed's price will affect the production costs and the profits which gain from aquaculture. One of which can be used as an alternative of feed ingredient is Swangi's waste on surimi products. One of the attempts of waste reduction is through a chemical process. The chemical process is adding the organic acids namely formic acid and propionic acid. This study used experimental methods with Rancangan Acak Lengkap (RAL). The treatment consisted of the addition of organic acids as $0 \%(\mathrm{P} 0), 1,5 \%(\mathrm{P} 1), 3 \%(\mathrm{P} 2)$, dan $4,5 \%(\mathrm{P} 3)$ with four-time repetition of each time. The parameter which observed was the nutrition content after 7 days. Analysis of Variance (ANOVA) used to analyze the data and determined the best treatment the writer used Duncan's Multiple Range Testwith95\% confidence intervals. The result of the study showed that the addition of acid with different dosage on surimi products produces a significant difference of fish feed nutrition content $(\mathrm{p}<0.01)$. The best nutrition content found in P3 treatment with the protein crude $(51.0048 \%)$, fat $(8.6659 \%)$, fiber(3.9991), dry matter(88.6422\%), and ash by $(26.011 \%)$.
\end{abstract}

Keywords: propionad acid, soybean, nutrient, formiat acid and swanggi fish 


\section{Pendahuluan}

\section{Latar belakang}

Pakan adalah satu dari beberapa komponen penting dalam kegiatan budidaya intensif. Harga pakan akan mempengaruhi biaya produksi dan keuntungan yang diperoleh dari usaha budidaya sehingga dibutuhkan bahan baku pakan ikan yang murah dan lebih efisien (Kurniawati, 2012). Protein sebagai salah satu komponen utama pakan ikan yang umumnya berasal dari tepung ikan dan bungkil kedelai yang secara umum merupakan produk impor dengan harga yang relatif mahal yaitu $\mathrm{Rp} 14.408$ per $\mathrm{kg}$ tepung ikan dan Rp 4.700 per $\mathrm{kg}$ tepung kedelai (Atanpaim, 2010).

Limbah perikanan yang dapat digunakan salah satunya adalah limbah ikan swanggi (Priacanthus macracanthus) pada produk surimi. Park and Morrisey (2000) menyatakan bahwa proses pembuatan surimi meliputi penyiangan yang terdiri dari pembuangan kepala, organ dalam, kotoran dan tulang. Sampai saat ini limbah dari proses pengolahan surimi belum termanfaatkan dengan baik sedangkan ketersediannya terdapat dalam jumlah banyak.

Limbah ikan swanggi tidak dapat diberikan secara langsung kepada ikan karena dapat menimbulkan efek negatif yaitu cepat rusak dan busuk sehingga perlu dilakukan usaha untuk menambah nilai ekonomi dari limbah tersebut dengan cara kimiawi dan biologi. Proses secara kimiawi dilakukan dengan cara penambahan asam organik yaitu asam formiat dan propionat (Kompiang dan Ilyas, 1983). Menurut pernyataan Mukodiningsih dkk (2003), prinsip dari proses kimiawi ini adalah penurunan $\mathrm{pH}$ dari bahan tersebut.

Berdasarkan latarbelakang tersebut perlu penelitian lebih lanjut mengenai kajian tentang cara pemanfaatan limbah surimi ikan swanggi ( $P$. macracanthus) secara kimia dengan tujuan untuk memperoleh kandungan nutrisi bahan pakan yang berkualitas sehingga pemanfaatan limbah surimi ikan swanggi ( $P$. macracanthus) dalam ransum pakan diharapkan dapat mengurangi penggunaan tepung ikan yang sampai saat ini masih bernilai input relatif tinggi.

\section{Perumusan Masalah}

Berdasarkan latar belakang diatas, dapat dirumuskan permasalahan dalam penelitian ini, yaitu:

1.Apakah terjadi peningkatan kandungan protein kasar dan bahan kering pada pemanfaatan limbah surimi ikan swanggi $(P$. macracanthus) secara kimia?

2.Apakah terjadi penurunan kandungan lemak kasar, abu dan serat karat pada pemanfaatan limbah surimi ikan swanggi $(P$. macracanthus) secara kimia?

\section{Tujuan}

Tujuan dilakukannya penelitian ini yaitu: 1. Mengetahui peningkatan kandungan protein kasar dan bahan kering pada pengolahan limbah surimi ikan swanggi (P. macracanthus) secara kimia.

2. Mengetahui penurunan kandungan lemak kasar abu dan serat kasar pada pengolahan limbah surimi ikan swanggi (P. macracanthus) secara kimia.

\section{Manfaat Penelitian}

Hasil penelitian ini diharapkan dapat memberikan informasi kepada pembaca, dan pembudidaya ikan mengenai kandungan limbah surimi ikan swanggi (P. macracanthus) sehingga dapat digunakan sebagai alternatif bahan pakan pada ransum pakan buatan sehingga dapat menghemat biaya produksi pakan ikan.

\section{Materi dan Metode \\ Waktu dan Tempat}

Penelitian dilakukan di Fakultas Perikanan dan Kelautan Universitas Airlangga dan Analisis Proksimat dilaksanakan di Laboratorium Pakan Ternak Fakultas Kedokteran Hewan Universitas Airlangga.Penelitian ini dilakukan pada 12 April 2014.
Diterima/submitted:29 September 2014 Disetujui/accepted:1 Maret 2016 
Alat dan Bahan

Alat yang digunakan pada penelitian ini terdiri dari oven, gilingan, toples kaca, baki, spuit, $\mathrm{pH}$ meter, timbangan digital, gelas ukur, botol sprayer dan sendok.

Bahan-bahan yang digunakan dalam penelitian ini adalah limbah ikan Swanggi, asam propionat dan asam formiat.Limbah ikan Swangi diperoleh dari PT. Starfood Internasional sedangkan asam propionat dan asam formiat diperoleh dari PT. Sumber Utama.

\section{Metode Penelitian}

Rancangan penelitian yang digunakan adalah Rancangan Acak Lengkap (RAL) yang terdiri dari empat perlakuan dan lima ulangan. Menurut Kusriningrum (2008)

Penelitian kandungan protein kasar, lemak kasar, serat kasar, bahan kering dan abu dari limbah ikan swanggi dengan perlakuan sebagai berikut.

P0 : Limbah ikan swanggi

P1 : Limbah ikan swanggi + asam formiatdan asam propionat $1,5 \%$

P2 : Limbah ikan swanggi + asam formiat dan asam propionat $3 \%$

P3 : Limbah ikan swanggi + asam formiat dan asam propionat $4,5 \%$

\section{Prosedur Kerja}

Limbah ikan swanggi dibersihkan terlebih dahulu selanjutnya dikeringkan dengan menggunakan oven pada suhu $50{ }^{\circ} \mathrm{C}$. Setelah limbah kering digiling sampai berbentuk tepung dan ditimbang 50 gram dengan menggunakan timbangan digital untuk masing-masing perlakuan dan ulangan. Asam formiat dan propionat disiapkan dengan dosis sebanyak 1,$5 ; 3$; dan $4,5 \%$ dari berat total bahan kering dengan perbandingan asam formiat : propionat 1:1. Campuran tersebut dimasukkan dalam toples kaca dan diaduk 3-4 kali setiap hari selama empat hari, kemudian hari ke-5 sampai ke-7 diaduk satu kali sehari.Setelah selesai dilakukan analisis proksimat.
Setelah tujuh hari juga dilakukan pengamatan organoleptik dengan mengambil sedikit sampel kemudian diamati secara keseluruhan hasil proses pemanfaatan limbah secara kimiawi yang meliputi pengamatan secara fisik dengan kriteria yang dinilai adalah rupa, bau, dan konsistensi. Penilaian organoleptik dilakukan secara skoring.

\section{Parameter Uji}

Parameter utama yang diamati pada penelitian ini adalah nilai kandungan protein kasar, lemak kasar, serat kasar, bahan kering dan abu.Protein kasar, lemak kasar, serat kasar, bahan kering dan abu dapat diketahui melalui analisis proksimat.Prosedur pemeriksaan dapat dilihat pada lampiran 2 sampai 8.Parameter penunjang yang diamati dalam penelitian ini adalah pemeriksaan organoleptik.

\section{Analisis Data}

Data yang diperoleh, diolah dengan menggunakan Analysis of Variance (ANOVA) untuk mengetahui apakah terdapat perbedaan antara perlakuan yang diberikan. Jika terdapat perbedaan, maka dilanjutkan dengan uji Jarak Berganda Duncan (Duncan's Multiple Range Test) dengan taraf nyata $\alpha=0,05$ atau tingkat kepercayaan 95\% untuk mengetahui perlakuan mana yang memberikan hasil tertinggi dan terendah (Kusriningrum, 2008).

\section{Hasil dan Pembahasan Kandunga Protein Kasar}

Tabel 1. Kandungan Rata-Rata Protein Kasar Berdasarkan Bahan Kering (\%) Pada Setiap Perlakuan

\begin{tabular}{cl}
\hline Perlakuan & Rata-rata protein kasar \pm SD \\
\hline P0 & $47.9449 \pm 0.4963$ \\
P1 & $50.3295 \pm 0.5361$ \\
P2 & $50.3467 \pm 1.0966$ \\
P3 & $51.0048^{\mathrm{a}} \pm 0.5759$ \\
\hline
\end{tabular}

Uji statistik menunjukkan bahwa penambahan asam dengan dosis yang berbeda menghasilkan kandungan protein kasar limbah surimi yang berbeda sangat nyata
Diterima/submitted:29 September 2014

Disetujui/accepted:1 Maret 2016 
$(\mathrm{p}<0,01)$. Setelah dilanjutkan dengan uji Jarak Berganda Duncan (Duncan's Multiple Range Test) dapat diketahui bahwa kandungan protein kasar tertinggi terdapat pada perlakuan P3 yang berbeda nyata dengan perlakuan P0meskipun tidak berbeda nyata dengan perlakuan P1 dan P2, sedangkan kandungan protein kasar terendah didapatkan pada perlakuan $\mathrm{P} 0$.

\section{Kandungan Lemak Kasar}

Tabel 2. Kandungan Rata-Rata Lemak Kasar (\%) Berdasarkan Bahan Kering Pada Setiap Perlakuan

\begin{tabular}{cl}
\hline Perlakuan & \multicolumn{1}{c}{ Rata-rata lemak kasar \pm SD } \\
\hline P0 & $7.0062 \pm 0.9613$ \\
P1 & $9.0229 \pm 0.751$ \\
P2 & $9.1707 \pm 0.7066$ \\
P3 & $8.6659 \pm 0.457$
\end{tabular}

Uji statistik menunjukkan bahwa penambahan asam dengan dosis yang berbeda menghasilkan kandungan lemak kasar yang berbeda sangat nyata $(\mathrm{p}<0,01)$. Setelah dilajutkan dengan uji Jarak Berganda Duncan (Duncan's Multiple Range Test) dapat diketahui bahwa kandungan lemak kasar tertinggi terdapat pada perlakuan P2 yang berbeda nyata dengan perlakuan P0meskipun tidak berbeda nyata dengan perlakuan P1 dan P3, sedangkan kan-dungan lemak kasar terendah didapatkan pada perlakuan $\mathrm{P} 0$.

\section{Kandungan Serat Kasar}

Tabel 3. Kandungan Rata-Rata Serat Kasar (\%) Berdasarkan Bahan Kering Pada Setiap Perlakuan

\begin{tabular}{cc}
\hline Perlakuan & Rata-rata Serat Kasar \pm SD \\
\hline P0 & $6.1501 \pm 0.9146$ \\
P1 & $4.9994 \pm 1.0769$ \\
P2 & $4.9487 \pm 0.3887$ \\
P3 & $3.9991 \pm 0.5370$ \\
\hline Uji statistik menunjukkan bahwa \\
penambahan asam dengan dosis yang \\
berbeda mengasilkan kandungan serat kasar \\
limbah surimi yang berbeda sangat nyata \\
(p<0,01). Setelah dilajutkan dengan uji \\
Jarak Berganda Duncan (Duncan's Multiple \\
Range Test) dapat diketahui bahwa
\end{tabular}

kandungan serat kasar tertinggi terdapat pada perlakuan P0 yang berbeda nyata dengan perlakuan P3, sedangkan kandungan serat kasar terendah didapatkan pada perlakuan P3 walaupun tidak berbeda nyata dengan perlakuan P1 dan P2.

\section{Kandungan Bahan Kering}

Tabel 4. Kandungan Rata-Rata Bahan kering (\%) Pada Setiap Perlakuan

\begin{tabular}{cc}
\hline Perlakuan & Rata-rata Bahan Kering \pm SD \\
\hline P0 & $93.5032 \pm 0.5375$ \\
P1 & $92.0270 \pm 0.8621$ \\
P2 & $90.1004 \pm 0.4374$ \\
P3 & $88.6423 \pm 0.3959$ \\
\hline Uji statistik menunjukkan bahwa \\
penambahan asam dengan dosis yang ber- \\
beda mengasilkan kandungan bahan kering \\
limbah surimi yang berbeda sangat nyata \\
$(\mathrm{p}<0,01)$.
\end{tabular}

Setelah dilajutkan dengan uji Jarak Berganda Duncan (Duncan's Multiple Range Test) dapat diketahui bahwa kandungan kandungan bahan kering tertinggi terdapat pada perlakuan P0 yang berbeda nyata dengan semua perlakuan, sedangkan kandungan bahan kering terendah didapatkan pada perlakuan $\mathrm{P} 3$.

\section{Kandungan Abu}

Tabel 5. Kandungan Rata-Rata Abu (\%) Berdasarkan Bahan Kering Pada Setiap Perlakuan

\begin{tabular}{cl}
\hline Perlakuan & Rata-rata Abu \pm SD \\
\hline P0 & $28.6796 \pm 1.677$ \\
P1 & $27.1626 \pm 0.846$ \\
P2 & $26.1722 \pm 0.902$ \\
P3 & $26.0111 \pm 0.548$ \\
\hline
\end{tabular}

Uji statistik menunjukkan bahwa penambahan asam dengan dosis yang ber-beda menghasilkan kandungan abu yang berbeda sangat nyata $(p<0,01)$. Setelah dilajutkan dengan uji Jarak Berganda Duncan (Duncan's Multiple Range Test) dapat dike-tahui bahwa kandungan abu tertinggi terdapat pada perlakuan P0 yang tidak berbeda nyata dengan perlakuan P1.Kandungan abu terendah didapatkan pada perlakuan P2 dan P3
Diterima/submitted:29 September 2014

Disetujui/accepted:1 Maret 2016 
walaupun tidak berbeda nyata dengan perlakuan P1.

\section{Uji Organoleptik}

Berdasarkan uji Kruskal-Wallis seperti yang terdapat pada Lampiran 14 dapat diketahui bahwa proses pemanfaatan limbah secara kimiawi dengan penambahan asam $1,5 \%, 3 \%$ dan $4,5 \%$ tidak berbeda nyata dengan kontrol. Hal ini berarti penggunaan asam dengan dosis yang berbeda tidak berpengaruh nyata terhadap penampakan limbah surimi. Nilai organoleptik kenampakan rata-rata limbah surimi ikan Swanggi tanpa penambahan asam dengan penambahan asam sebesar $1,5 \%$ adalah 8,2 . Ratarata perlakuan untuk penampakan asam sebesar 3\% dan 4,5\% yaitu 7,48 dan 7,08.

Uji organoleptik terhadap bau pada masing-masing perlakuan terdapat berbeda sangat nyata seperti terlihat pada Lampiran 15.Hal ini menunjukkan bahwa penggunaan asam dengan dosis berbeda berpengaruh sangat nyata terhadap bau. Limbah surimi ikan Swanggi dengan perlakuan yang ditambah asam 3\% dan 4,5\% mempunyai nilai organoleptik bau rata-rata 6,52 dan 5,59 sedangkan untuk perlakuan dengan penambahan asam 1,5 dan kontrol menujukkan rata-rata 6,84 dan 7,48 .

Hasil uji organoleptik konsistensi menunjukkan hasil yang sama dengan penampakan yaitu penambahan asam 1,5\%, 3\% dan $4,5 \%$ tidak berbeda nyata dengan kontrol. Hal ini berarti penggunaan asam dengan dosis yang berbeda tidak berpengaruh nyata terhadap konsistensi. Nilai organoleptik konsistensi rata-rata limbah surimi ikan Swanggi tanpa penambahan asam adalah 6,84. Rata-rata perlakuan untuk penambahan asam sebesar 1,5\%, 3\% dan 4,5\% yaitu $6,12,5,58$ dan 5,56 .

\section{Pembahasan \\ Kandungan Protein Kasar}

Penelitian ini dilakukan pengamatan pemanfaatan limbah surimi ikan Swanggi secara kimia dengan dilakukan penambahan
asam.Hasil analisis statistik pada masingmasing perlakuan dengan dosis yang berbeda menunjukkan adanya perbedaan yang sangat nyata terhadap kandungan protein kasar limbah surimi Ikan Swanggi. Tabel 3 menunjukkan bahwa kandungan protein limbah surimi ikan Swanggi pada P0, P1, P2 dan P3 adalah sebesar 47,9449\%,50,3295\%, $50,3467 \%$ dan 51,0048\%. Pada penelitian menunjukkan perlakuan P3 dengan rata-rata kandungan protein kasar tertinggi yaitu sebanyak 51,0048\%.

Peningkatan kandungan protein kasar pada limbah surimi ikan swanggi disebabkan karena adanya penambahan asam dengan dosisi yang berbeda. Semakin tinggi asam yang digunakan menyebabkan suasana menjadi asam. Suasana asam dapat menyebabkan bakteri patogen yang ada di dalam media/substrat akan terhambat partumbuhannya hal ini mengakibatkan mikroba yang ada di dalam tubuh ikan dapat berkembang dengan baik. Berdasarkan penelitian yang dilakukan oleh Aslamyah dkk (2009) bakteri yang terdapat pada ikan antara lain Staphyloccus sp., Clostridium sp., Bacillus sp., Moraxella sp., Lactocillus sp., Nitrococcus sp., Aeromonas sp., Mycobacterium sp., Lactobacillus sp., Carnobacterium sp., Citrobacter sp., dan Streptococcus sp., Pada peningkatan kandungan protein bakteri yang berperan adalah Lactobacillus. Lactobacillus dapat tumbuh tanpa adanya kompetisi dengan bakteri patogen sehingga dapat berkembang dengan baik.Mikroba tersebut menghasilkan enzim protease yang mampu memecah protein menjadi peptida yang lebih sederhana kemudian dipecah lagi menjadi asam amino, sehingga asam amino tersebut dapat dimanfaatkan mikroba untuk berkembangbiak. Meningkatnya jumlah koloni mikroba selama proses secara tidak langsung dapat meningkatkan protein kasar dari suatu bahan karena mikroba ini merupakan protein sel tunggal (Priskila, 2007). Protein sel tunggal merupakan istilah yang digunakan untuk protein kasar murni yang berasal dari mikroorganisme bersel satu atau

Diterima/submitted:29 September 2014

Disetujui/accepted:1 Maret 2016 
banyak yang sederhana, seperti bakteri, khamir, jamur, ganggang, dan protozoa (Sumarlin, 2010).

Peningkatan kandungan protein kasar juga didukung oleh pendapat Abun (2006) bahwa penambahan asam organik (asam formiat dan propionat dengan perbandingan 1:1) dapat mencegah kerusakan protein melalui pengoksidasian media/substrat (dalam hal ini limbah surimi ikan Swanggi) menjadi suasana asam. Suasana asam akan menghambat kerja dari bakteri pembusuk, apabila aktivitas bakteri pembusuk yang masih tersimpan dalam limbah tidak dihambat maka akan terjadi pembusukan yang menyababkan kualitas protein menurun.

\section{Kandungan Lemak Kasar}

Pemanfaatan limbah surimi ikan swanggi secara kimia yang dilakukan dengan menambahkan asam formiat dan propionat dengan penyimpanan selama tujuh hari secara aerobdiperoleh hasil analisis statistika pada masing-masing perlakuan dengan dosis yang berbeda, menunjukkan adanya perbedaan yang sangat signifikan terhadap kandungan lemak kasar limbah surimi Ikan Swanggi. Tabel 4 menunjukkan kandungan lemak kasar limbah surimi ikan pada P0, P1, P2 dan P3 adalah 7,0062\%, 9,0229\%, $9,1707 \%$ dan $8,6659 \%$. Kandungan lemak tertinggi terjadi pada perlakuan P2 yaitu $9,1707 \%$ dengan dosis $3 \%$. Perlakuan terendah adalah $\mathrm{P} 0$ dengan dosis penambahan asam $0 \%$ (kontrol).

Lemak dapat dikelompokkan menjadi lipid sederhana, lipid komposit, spingolipid, dan lipid turunan.Lipid sederhana adalah yang mengandung dua jenis komponen penyusun, yaitu ester gliserin (ester asam lemak dan gliserin), ester kolesterol (ester kolesterol dan gliserin), wax (ester asam lemak dan alkohol), dan keramid (ester amid dan asam lemak).Lemak atau minyak termasuk dalam lipid sederhana dari ester gliserol yang disusun oleh asam lemak dan gliserin.Hal ini menyebabkan penambahan asam formiat dan propionat diduga berpengaruh pada kandungan lemak kasar.Asam formiat dan propionat termasuk dalam kelompok asam karboksilat atau asam lemak (Kusnandar, 2010).Menurut Fressenden and Fressenden (1992) asam karboksilat diperoleh dari hidrolisis suatu lemak atau minyak.Penambahan asam karboksilat atau asam lemak terikat pada gliserol melalui ikatan kovalen sehingga dapat terbentuk ester gliserol.Ikatan yang terbentuk adalah antara gugus karboksil pada asam lemak dan gugus hidroksil pada gliserin. Setiap pembentukan ikatan kovalen akan membebaskan satu molekul air sehingga reaksinya disebut reaksi polimerasi kondensasi, karena gliserin memiliki tiga gugus hidroksil maka gliserin dapat mengikat maksimum tiga rantai asam lemak dan dapat melepaskan maksimal tiga molekul air untuk membentuk trigliserida. Terbentuknya trigliserida menyebabkan kandungan lemak kasar mengalami penambahan atau peningkatan. Hal tersebut sesuai dengan penelitian limbah surimi yang terjadi peningkatan kandungan lemak kasar pada perlakuan yang ditambahkan asam dibandingkan perlakuan yang tidak ditambahkan asam atau kontrol.

\section{Kandungan Serat Kasar}

Limbah yang ditambahkan asam dan disimpan selama 7 hari yang disajikan pada tabel 6 dan hasil analisis varian (ANOVA) menunjukkan bahwa penambahan asam memberikan pengaruh yang sangat nyata pada penurunan kandungan serat kasar limbah surimi ikan Swanggi. Kandungan serat kasar terendah adalah perlakuan P3 sebesar 3,9991\% yang berbeda nyata dengan perlakuan P0 dengan kandungan serat kasar 6,15014\%. Perlakuan P1 dan P2 memiliki kandungan serat kasar sebanyak 5, 9994\% dan 4,9487.

Menurunnya kadar serat kasar disebabkan karena dalam suasana asam maka akan terdapat bakteri tahan asam misalnya Bacillus yang secara alamiah terdapat pada lingkungan sehingga akan tumbuh dan berkembang. Selain itu didalam tubuh ikan sen-

Diterima/submitted:29 September 2014 Disetujui/accepted:1 Maret 2016 
diri terdapat Bacillus yang terdapat pada saluran pencernaan.Bacillusmerupakan bakteri selulolitik yang akan mengeluarkan enzim selulase. Enzim selulase merupakan enzim kompleks yang terdiri dari enzim endoselulase dan eksoselulase (Setyono, 2004). Enzim selulase akan memecah selulosa menjadi selubiosa, selanjutnya menjadi glukosa dimana glukosa merupakan salah satu komponen serat kasar (Setyono, 2004).

\section{Kandungan Bahan Kering}

Limbah yang ditambahkan dengan asam formiat dan propionat selama tujuh hari yang disajikan pada tabel 7 dan hasil Analisis Varian (ANOVA) menunjukkan bahwa penambahan asam tersebut memberikan pengaruh yang sangat nyata pada penurunan kandungan bahan kering $(p<0,01)$. Penurunan kandungan bahan kering dimulai dari perlakuaantanpa penambahan asam untuk kontrol (P0) untuk asam, 1,5\% (P1), 3\% (P2), dan 4,5\% (P3)dengan nilai rata-rata kandungan bahan keringsebesar 93,5032\%, $92,0270 \%, 90,1004 \%$, dan $88,6423 \%$.

Dari keempat perlakuan yang dilakukan dalam penelitian diperoleh hasil penelitian P3 lebih rendah dari perlakuan lain (P0, P1, dan P2). Menurunnya kandungan bahan kering mungkin dipengaruhi zat nutrien yang terkandung dalam bahan organik dan anorganik yang merupakan komponen penyusun bahan kering. Nutrien yang terkandung dalam bahan organik merupakan penyusun bahan kering terdiri dari lemak, protein kasar dan serat kasar. Bahan kering merupakan komposisi yang sama dengan bahan organik ditambah abu (Kamal, 1994). Asam memberikan pengaruh secara tidak langsung terhadap kandungan bahan kering yang menyebabkan penurunan pada nilai kandungan nutrisi bahan kering terutama kandungan bahan organik. Selain itu asam formiat dan asam propionat dalam bentuk cair. Kondisi asam yang diberikan dalam bentuk cair juga mempengaruhi penurunan kandungan bahan kering dari limbah surimi ikan Swanggi. Hal tersebut didukung oleh pendapat Ferdianz (1992) bahwa semakin banyak cairan atau air pada bahan pakan akan menyebabkan bahan sering semakin menurun dan juga berpengaruh pada kandungan serat kasar.

\section{Kandungan Abu}

Abu adalah bahan anorganik hasil sisa pembakaran sempurna dari suatu bahan yang dibakar/dipanaskan pada suhu 500-600 ${ }^{0} \mathrm{C}$ (Agustono dkk., 2011). Kandungan abu dapat diketahui dengan melakukan analisis proksimat pada bahan pakan tersebut. Limbah surimi ikan Swanggi yang ditambahkan asam dengan dosis yang berbeda yaitu $1,5 \%, 3 \%$ dan $4,5 \%$ menunjukkan perbedaan yang sangat nyata diantara perlakuan.

Uji statistik menunjukkan bahwa penambahan asam dengan dosis yang berbeda mengasilkan kandungan abu limbah surimi yang berbeda sangat nyata $(p<0,01)$. Setelah dilajutkan dengan uji Jarak Berganda Duncan (Duncan's Multiple Range Test) dapat diketahui bahwa kandungan kandungan abu tertinggi terdapat pada perlakuan P0 $(28,6796 \%) y a n g$ berbeda nyata dengan perlakuan P3. Kandungan abu terendah didapatkan pada perlakuan P3 (26,0111\%) walaupun tidak berbeda nyata dengan perlakuan P1 dengan kandungan sebesar $27,1626 \%$ dan P2 26,1722\%.

Penambahan asam formiat dan propionat yang merupakan asam organik, pada saat pengabuan zat organik tersebut ikut terbakar.Penambahan asam menyebabkan pembakaran berjalan lebih cepat sehingga zat-zat organik terbakar sempurna sedangkan zat anorganik tidak mengalami pembakaran (Noviana, 2012).Sudarmadji dkk (1997) menyatakan bahwa abu adalah zat anorganik sisa pembakaran yang berhubungan dengan jumlah mineral pada bahan pakan.Penambahan asam diduga perpengaruh pada kandungan mineral. Munzilin (2000) menyatakan rendahnya kadar abu disebabkan oleh terlarutnya mi-
Diterima/submitted:29 September 2014

Disetujui/accepted:1 Maret 2016 
neral pada saat hidrolisis dengan asam atau disebut demineralisasi.

Demineralisasi adalah hilangnya mineral karena terlarut dalam asam.Kecepatan melarutnya mineral dipengaruhi oleh konsentrasi asam dan waktu melarut.Penambahan asam formiat dan propionat dapat menyebabkan terlarutnya mineral yang terdapat pada tulang.Mineral utama yang terdapat pada tulang adalah kalium dan fosfat dalam bentuk senyawa kalium fosfat. Asam tersebut akan merusak ikatan senyawa kalium fosfat sehingga akan berbentuk ion-ion sehingga ion-ion tersebut akan larut dalam asam (Prasetyo, 2005). Hal ini mengakibatkan kandungan mineral mengalami penurunan. Menurunnya jumlah mineral akan menurunkan kanadungan abu. Hal ini sesuai dengan penelitian yang menunjukkan penurunan kandungan abu dari $28,6796 \%$ menjadi $26,0111 \%$.

$\mathrm{Abu}$ pada tepung ikan mengandung mineral yang diperlukan oleh antara lain kalsium dan fosfor yang merupakan komponen terbesar tulang ikan. Bahan baku sangat mempengaruhi kadar abu dari tepung ikan, bahan baku yang mengandung banyak tulang dapat menyebabkan tingginya kadar mineral tepung ikan. Rendahnya kadar abu bisa disebabkan oleh terlarutnya mineralmineral pada saat hidrolisis dengan asam. Sesuai dengan penelitian ini yang menggunakan limbah surimi ikan Swanggi yang sebagian besar komponenen terbesarnya adalah tulang (Munzilin, 2000).

\section{Uji Organoleptik}

Selain hasil analisis proksimat penelitian organoleptik juga perlu dilakukan.Penilaian organoleptik meliputi kenampakan, bau dan konsistensi.Penilaian organoleptik dapat digunakan sebagai parameter untuk menentukan penerimaan terhadap hasil penelitian dan apakah memenuhi persyarat Standar Nasional Indonesia.Penelitian organoleptik dilakukan oleh 25 panelis dan untuk mengetahui produk mana yang terbaik di- antara perlakuan dilakukan uji KruskalWallis.

Berdasarkan uji Kruskal-Wallis dapat diketahui bahwa proses pemanfaatan limbah secara kimiawi dengan penambahan asam (asam formiat dan propionat) sebanyak $1,5 \%, 3 \%$ dan $4,5 \%$ tidak berbeda nyata dengan kontrol. Hasil dari penilaian organoleptik menunjukkan diantara perlakuan tidak terdapat perbedaan yang nyata. Nilai kenampakan rata-rata limbah surimi ikan Swanggi tanpa penambahan asam dengan penambahan asam sebesar 1,5\% mempunyai nilai yang sama yaitu 8,2 dengan kriteria cukup bersih, normal dan cerah. Rata-rata perlakuan untuk kenampakan asam sebesar 3\% dan 4,5\% pada P2 dan P3 yaitu 7,48 dan 7,08 yang termasuk dalam kriteria kurang bersih, normal dan cerah. Hal ini berarti penggunaan asam dengan dosis yang berbeda tidak berpengaruh nyata terhadap kenampakan limbah surimi.

Uji organoleptik terhadap bau pada masing-masing perlakuan mempunyai bau yang berbeda sangat nyata.Hal ini $\mathrm{m}$ enunjukkan bahwa penggunaan asam dengan dosis berbeda berpengaruh sangat nyata terhadap bau pada hasil pemanfaatan limbah surimi ikan Swanggi secara kimia. Limbah yang ditambahkan asam dengan dosisi $4,5 \%$ bau asamnya sangat kuat dan menyengat jika dibandingkan dengan perlakuan lainnya. Limbah surimi ikan Swanggi dengan perlakuan yang ditambah asam 3\% dan mempunyai nilai organoleptik bau rata-rata 6,52 dengan spesifikasi tepung ikan dan kurang harum. Perlakuan P3 dengan penambahan dosisi 4,5\% memiliki nilai organoleptik 5,59 dengan spesifikasi adanya bau tambahan dan netral. Bau tambahan dalam hal ini disebabkan oleh adanya penambahan asam sebanyak 4,5\%, sedangkan untuk perlakuan dengan penambahan asam 1,5\% dan kontrol menujukkan rata-rata 6,84 dan 7,48 dengan spesifikasi cukup harum dan spesifikasi tepung ikan.

Hasil uji organoleptik konsisitensi menunjukkan hasil yang sama dengan pe-

Diterima/submitted:29 September 2014

Disetujui/accepted:1 Maret 2016 
nampakan yaitu penambahan asam tidak berbeda nyata dengan kontrol. Hal ini berarti penggunaan asam dengan dosis yang berbeda tidak berpengaruh nyata terhadap konsistensi limbah surimi. Nilai organoleptik konsistensi rata-rata limbah surimi ikan Swanggi tanpa penambahan asam adalah 6,84. Limbah yang dihasilkan mempunyai konsistensi yang tidak menggumpal dan cukup kering. Perlakuan untuk penambahan asam sebesar 1,5\%, 3\% dan 4,5\% memiliki spesifikasi tidak menggumpal, agak kering dan halus.

\section{Simpulan}

Berdasarkan hasil yang diperoleh pada penelitian pemanfaatan limbah surimi ikanSwanggi sacara kimia maka dapat ditarik kesimpulan sebagai berikut:

1) Pemanfaatan limbah padat surimi ikan Swanggi secara kimia dengan penambahan asam memberikan pengaruh yang sangat nyata terhadap kenaikan kadar protein kasar dan lemak kasar limbah surimi ikan Swanggi.

2) Pemanfaatan limbah padat surimi ikan Swanggi secara kimia dengan penambahan asam memberikan pengaruh yang sangat nyata terhadap penurunan kadar serat kasar, abu dan bahan kering pada limbah surimi ikan Swanggi..

\section{Saran}

Berdasarkan hasil penelitian yang telah dilakukan, pemanfaatan limbah padat surimi ikan Swanggi secara kimia dapat meningkatkan kandungan nutrisi dari limbah tersebut, sehingga dapat digunakan pada sebagai alternatif bahan pakan dengan harapan dapat mengurangi biaya pakan dalam budidaya. Dapat dilakukan penelitian lanjutan terhadap laju pertumbuhan, efisiensi pakan, nilai retensi protein, lemak dan energi pada ikan Nila.

\section{Daftar Pustaka}

Abun.2006. Efek Pengolahan Secara Kimia dan Biologi Terhadap Kandungan Gizi dan Nilai Energi Metabolis Limbah Ikan Tuna Pada Ayam Broiler. Jurnal Bionatura. 3 (VII) : 282

Aslamyah, S., H. Y. Azis., Sriwulan., K. G. Wiryawan. Mikroflora Saluran Pencernaan Ikan Gurame (Osphronems gourami Lacepede). Jurnal Ilmu Kelautan dan Perikanan. 19 (1) : 70

Fardiaz. 1992. Mikrobiologi Pangan 1. Gramedia Pustaka Utama. Jakarta.

Fressenden and Fressenden. 1992. Kimia Organik. Airlangga Press. Surabaya Alih Bahasa: Aloysius Hadyana Pudjaatmaka, Ph. D.

Kamal. 1994. Nutrisi Ternak 1. Laboratorium Makanan Ternak.Jurusan Nutrisi dan Makanan Ternak. Fakultas Peternakan. Universitas Gajah Mada. Yogyakarta.

Kurniawati, F. 2012. Peningkatan Kecernaan Kulit Ubi Kayu Manihot Utilissima Setelah Perendaman $\mathrm{NaOH}$, Fermentasi Kapang, dan Fermentasi Bakteri sebagai Bahan Baku Pakan Ikan Nila Oreochromis Niloticus. Skripsi. Budidaya Perairan. Fakultas Perikanan.Institut Pertanian Bogor.Bo-gor.

Kusnandar, F. 2010. Kimia Pangan. PT. Dian Rakyat. Jakarta. Hal 168

Kusriningrum. 2008. Perancangan Percobaan. Airlangga University Press. Surabaya. Hal 65-125.

Muis. A., C. Khairani., Sukarjo, dan Y. P. Rahardjo. 2008. Petunjuk Tehnik Teknologi Pendukung Pengembangan Agribisnis di Desa P4MI. Badan Penelitian dan Pengembangan Pertanian. Balai Pengkajian Teknologi Pertanian. Sulawesi Tengah.

Mukodingsih, B. Sulistiyono dan V. D. yunianto. 2003. Kajian Pengaruh Suhu Pengeringan Terhadap Kadar Protein, Kalsium dan Fosfor Tepung Silase ikan. www.balit-angjateng.go.id. [19 Maret 2014]

Munzilin, I. K. 2000. Studi Tentang Karakteristik Tepung Ikan Tembang (Sardinella fimbrata) Hasil Reaksi Hidro-

Diterima/submitted:29 September 2014 Disetujui/accepted:1 Maret 2016 
lisis/Plastein Menggunakan Enzim Tripsin dan Pepsin Terimobil.Skripsi. Program Studi Teknologi Hasil Perikanan. Fakultas Perikanan dan Ilmu Kelautan. Institut Pertanian Bogor. Bogor

Park, J. W., and Morrissey, M. T. 2000. Manufacturing of Surimi From Light Muscle Fish. Edited by Park J. W. Surimi and Surimi Seafood. New York: Marcel Dekker Inc.

Priskila, F. 2007. Pengaruh Penggunaan Kombucha terhadap Kandungan Protein Kasar dan Serat Kasar pada Fermentasi Daun Talas (Colocosia esculenta).Skripsi. Program Studi S1 Budidaya Perairan. Fakultas Kedokteran Hewan. Universitas Airlangga. Surabaya. 55 hal

Setyono dan S. Yudo.2008. Potensi Pencemaran Dari Limbah Cair Industri Pengolahan Ikan Di Kecamatan Muncur, Kabupaten Bayuwangi.Jurnal. 4 (2) $: 1$

Sudarmadji, S., B, Haryanto dan Suhardi. 1997. Prosedur Analisa Bahan Makanan dan Pertanian. Liberty. Jakarta.

Sumarlin. 2010. Protein Sel Tunggal. Laboratorium Kimia.Universitas Haluoleo.Kendari.14 hal.

Sudarmaji, S. B. Haryanto dan Suhardi. 1997. Prosedur Analisis Bahan Makanan dan Pertanian. Liberti. Jakarta. 